\title{
Mudanças das emissões otoacústicas por transientes na supressão contralateral em lactentes $* * *$
}

\author{
Changes in transient evoked otoacoustic emissions contralateral \\ suppression in infants
}

\begin{abstract}
Alessandra Spada Durante* (asdurant@usp.br)
Renata Mota Mamede Carvallo**
\end{abstract}

**Fonoaudióloga. Doutora em Ciências pela Faculdade de Medicina da Universidade de São Paulo. Professora Assistente do Curso de Fonoaudiologia da Faculdade de Ciências Médicas da Santa Casa de São Paulo. Endereço para correspondência: R. Dr. Cesário Mota Júnior, $61-8^{\circ}$. Andar - São Paulo - SP CEP 01221-020 (asdurant@usp.br).

**Fonoaudióloga. Professora LivreDocente Associada do Curso de Fonoaudiologia da Faculdade de Medicina da Universidade de São Paulo.

****Trabalho Desenvolvido no Hospital Universitário da Universidade de São Paulo

\begin{abstract}
Background: it has been suggested that the function of the medial olivocochlear system (MOCS) can be evaluated by the suppression effect of the transient evoked otoacoustic emission (TEOAE). The competitive noise has an inhibitory effect on the functioning of the outer hair-cell, reducing the level of otoacoustic emissions. Despite the fact that there is no postnatal growth of the cochlea, middle ear growth and auditory processing development continue after birth. Aim: to analyze age-related changes of MOCS using the TEOAE suppression in healthy infants. Method: 25 full-term infants with no risk factors for hearing loss were evaluated in two moments: at birth and at the age of six months. At both ages TEOAE were recorded in the "Quickscreen" mode, nonlinear stimulation at 78dB peSPL, for both ears, with and without contralateral noise presented at 60dB SPL. Results: the data analyses, using ANOVA, revealed significant contralateral suppression of otoacoustic emissions in both groups, but the TEOAE levels and the amount of TEOAE contralateral suppression were smaller at six-month of age when compared to the neonatal period $(\mathrm{p}<0,01)$. The TEOAE suppression effect for neonatals was $2.81 \mathrm{~dB}( \pm 0.19 \mathrm{~dB})$ and at the age of six months was $1.41 \mathrm{~dB}( \pm 0.29 \mathrm{~dB})$. Conclusion: the amount of TEOAE suppression decreased from birth to six months of age. The association between contralateral acoustic stimulation and a commercially available rapid TEOAE measurement system enables a noninvasive monitoring of the auditory efferent mechanism and seems to be clinically feasible to evaluate cochlear status and auditory efferent function development in infants at risk.
\end{abstract}

Key Words: Spontaneous Otoacoustic Emission; Suppression; Infants.

\section{Resumo}

Tema: tem sido sugerido que a função do sistema olivo coclear medial (SOCM) pode ser avaliada pelo efeito de supressão das emissões otoacústicas por transientes (EOAT). O ruído competitivo tem um efeito inibitório no funcionamento das células ciliadas externas reduzindo o nível das emissões otoacústicas. Apesar de não haver crescimento pós natal da cóclea, o crescimento da orelha média e o desenvolvimento do processamento auditivo continuam após o nascimento. Objetivo: analisar as mudanças no SOCM relacionadas à idade por meio da supressão das EOAT em lactentes saudáveis. Método: 25 lactentes a termo sem indicadores de risco auditivo foram avaliados em dois momentos: ao nascimento e no sexto mês de vida. Nas duas idades as EOAT foram captadas no modo "Quickscreen", estímulo clique não linear a 78dB peNPS, nas duas orelhas, com e sem ruído contralateral apresentado a 60dB NPS. Resultados: a análise dos dados por meio da ANOVA revelou significante supressão contralateral das EOAT em ambos grupos, porém tanto os níveis das EOAT quanto a magnitude da supressão contralateral das EOAT foram menores no sexto mês de vida quando comparados com a fase neonatal $(\mathrm{p}<0,01)$. O efeito de supressão das EOAT no período neonatal foi $2,81 \mathrm{~dB}( \pm 0,19 \mathrm{~dB})$ e no sexto mês de vida foi $1,41 \mathrm{~dB}( \pm 0,29 \mathrm{~dB})$. Conclusão: a magnitude da supressão das EOAT diminuiu do nascimento ao sexto mês de idade. A associação entre a estimulação acústica contralateral e um sistema, disponível comercialmente, rápido na medida das EOAT possibilita o monitoramento não invasivo dos mecanismos eferentes auditivos e parece ser clinicamente promissor na avaliação do estado coclear e do desenvolvimento da função eferente auditiva de lactentes de risco. Palavras-Chave: Emissões Otoacústicas Espontâneas; Supressão; Lactente.
Recebido em 27.08.2004. 03.01.2006; 3.03.2006. Aceito para Publicação em 3.03.2006. 


\section{Introduction}

Evoked otoacoustic emissions are sounds that can be recorded in the external ear canal in response to acoustic stimulation, and whose origin is thought to be the motile activity of outer hair cells. These cells are innervated by efferent nerve fibers of the medial olivocochlear system (MOCS). The myelinated medial system originates at the medial superior olive and its fibers end on the outer hair cells, predominantly at the opposite side. Only 24 to $26 \%$ of the medial efferent fibers are uncrossed (Warr,1979; Mulders and Robertson, 2002)).

It has been shown (Veuillet et al.,1991; Collet et al., 1990) that the competitive noise has an inhibitory effect on outer hair-cell functioning, and reduces the level of otoacoustic emissions (OAE). This effect named suppression of OAE cannot be explained in terms of technical artefacts, crosstalk or middle ear effect, giving evidence of MOCS involvement in the suppression of OAE in normal hearing human subjects (Collet et al., 1990).

The clinical relevance of MOCS was pointed out by various reviews (Hill et al., 1997; Azevedo, 2003; Carvallo, 2003), suggesting its involvement in the modulation of OAE, auditory sensitivity, signal detection in noise, activity within the cochlear nucleus, and in attention tasks. Activation of the MOCS, either by electric shocks in anaesthetised animals or by natural sound stimulation in awake animals, provides significant protection against both the temporary and the permanent harmful effects of acoustic over stimulation (Liberman and Kujawa, 1999).

The distribution of medial efferent fibers appears to mirror the pattern of ascending projections. The MOCS receives inputs predominantly from the contralateral cochlear nuclei, and the projections of medial efferent fibers are predominantly crossed (Warr, 1979), therefore, OAE suppression by a contralateral acoustic stimulation investigates predominantly the uncrossed medial system mechanisms.

Investigations conducted in neonates have shown that this effect is already present at term birth (Ryan; Piron,1994; Morlet et al., 1999; Abdala et al. 2000; Durante and Carvallo,2002). The morphological data also indicate that the human cochlea becomes structurally adult-like during the last trimester of pregnancy (Lavigne-Rebbilard and Pujol, 1988).

However, despite the fact that there was no postnatal growth of the cochlea (Eby; Nadol, 1986; Sato et al., 1991) middle ear growth (Eby; Nadol,1986) and central auditory processing development continue after birth; therefore, the question whether the OAE suppression effect observed at birth is the same as after six months of life still remains unanswered. A priori hypotheses points to changes in the pattern of suppression effect during development.

The aim of the present study was to conduct a study on MOCS function at birth and at six-month of age in the same normal hearing infants, using the TEOAE suppression.

\section{Method}

Subjects

Data were obtained from twenty-five healthy infants (16 females and 9 males) during the neonatal period and at six months of age. All infants had no risk factors for hearing loss (Joint Committee on Infant Hearing, 2000; CBPAI, 2000), and were full-term born at the University Hospital, University of Sao Paulo, and had TEOAE present bilaterally with a whole reproducibility level of at least $50 \%$.

\section{Procedure}

This research was performed in accordance with the principles of the Declaration of Helsink. Approval for this study was guaranteed by the local Ethics Committee (CAPPesq - HC 510/98). Parental consent was obtained for each neonate tested in this experiment .

The protocol consisted of a two-step test : at neonatal period and at six months of age.

At both ages the tests were carried out in a quiet room and all subjects were bilaterally tested.

After placing the earphone and the probe without disturbing the neonates, TEOAE were recorded first without and then with contralateral acoustic stimulation (CAS). Then, the same test procedure was followed for the other ear. 
TEOAE recordings and contralateral acoustic stimulation

TEOAE were recorded using the ILO288 Echoport OAE analyser (Otodynamics Ltda) and an E-type neonate probe. The Quickscreen mode was used. This mode employs a 'nonlinear click' stimulus elicited by an $80 \mu$ s electrical pulse at a rate of $80 / \mathrm{s}$, at the mean intensity of $78 \mathrm{dBpeak}$. The mean number of sweeps recorded in each condition was 100 . A recording window of 2.5$12.5 \mathrm{~ms}$ post-stimulus was used for analyses. A band-bass of 500-6000 Hz was employed.

The contralateral acoustic stimulation (CAS) was a $60 \mathrm{~dB}$ SPL white noise delivered by a CD player and presented by a $2 \mathrm{~cm}$ diameter earphone. The earphone output was calibrated before the tests with a sound level meter .

Data analysis

The following data was obtained for each TEOAE test: age; gender (male or female); ear (right or left); test condition (with or without CAS); TEOAE level (dB), TEOAE SNR level per frequency-band $(2.4 ; 3.2 ; 4.0 \mathrm{kHz})$.

TEOAE suppression was determined by subtracting the with CAS TEOAE level from the without CAS TEOAE level.
Measurement and statistics

The statistical analysis was performed using Pearson correlation, and analysis of variance (ANOVA) for repeated measures by the Statistical and mathematics Institute of São Paulo University (IME-USP). The significance level for the statistical tests was set at $5 \%(\mathrm{p}<0.05)$.

\section{Results}

The statistical analysis using ANOVA showed that with CAS and without CAS conditions for both ears and genders the measures were equivalent concerning intensity of the stimulus, stability, test time, and numbers of sweeps ( $p>0.419)$.

The TEOAE level behavior (Table 1) showed greater level at the neonatal period, in females and without CAS condition. Females have larger emission for the right ear compared to the left ear at both ages, while for males the opposite is observed at sixmonths of age. Females have larger emission compared to males, regardless of ear. Males and females show more suppression at the neonatal period for both ears.

TABLE 1. TEOAE mean levels and standard deviations (dBpeSPL) with and without CAS, according to gender, age and ear.

\begin{tabular}{|c|c|c|c|c|}
\hline \multirow{2}{*}{ Orelha } & \multirow{2}{*}{ Gênero } & \multirow{2}{*}{ EOAT } & \multicolumn{2}{|c|}{ Idade } \\
\hline & & & Período Neonatal & Sexto Mês de Vida \\
\hline \multirow{6}{*}{ direita } & \multirow{3}{*}{ Feminino } & sem EAC & $18,8(5,5 \mathrm{DP})$ & $16,8(5,4 \mathrm{DP})$ \\
\hline & & com EAC & $16,5(5,6 \mathrm{DP})$ & $15,1(5,7 \mathrm{DP})$ \\
\hline & & supressão & $2,3(2,5 \mathrm{DP})$ & $1,6(2,1 \mathrm{DP})$ \\
\hline & \multirow{3}{*}{ Masculino } & sem EAC & $16,6(4,6 \mathrm{DP})$ & $13,5(7,2 \mathrm{DP})$ \\
\hline & & com EAC & $13,1(6,4 \mathrm{DP})$ & $12,5(7,3 \mathrm{DP})$ \\
\hline & & supressão & $3,5(3,8 \mathrm{DP})$ & $1,6(1,4 \mathrm{DP})$ \\
\hline \multirow{6}{*}{ esquerda } & \multirow{3}{*}{ Feminino } & sem EAC & $16,6(6,0 \mathrm{DP})$ & $14,8(4,5 \mathrm{DP})$ \\
\hline & & com EAC & $14,3(6,4 \mathrm{DP})$ & $13,6(4,6 \mathrm{DP})$ \\
\hline & & supressão & $2,3(2,7 \mathrm{DP})$ & $1,2(1,7 \mathrm{DP})$ \\
\hline & \multirow{3}{*}{ Masculino } & sem EAC & $15,9(5,6 \mathrm{DP})$ & $14,4(5,4 \mathrm{DP})$ \\
\hline & & com EAC & $12,8(5,8 \mathrm{DP})$ & $13,6(5,3 \mathrm{DP})$ \\
\hline & & supressão & $3,1(2,9 \mathrm{DP})$ & $0,8(3,2 \mathrm{DP})$ \\
\hline
\end{tabular}


The analysis showed that all factors influenced TEOAE level. It was observed a reduction of the TEOAE level of the right ear to the left ear of about $1.29 \mathrm{~dB}( \pm 0.64 \mathrm{~dB})$ $(p=0.04)$. From the female to the male infants, a reduction of $1.54 \mathrm{~dB}( \pm 0.63 \mathrm{~dB})(\mathrm{p}=0.02 \mathrm{~dB})$ was observed. The statistical model showed that the TEOAE amount of suppression was different according to age $(\mathrm{p}<0.01)$. Graphic 1 shows that the OAE suppression effect at neonatal period was $2.81 \mathrm{~dB}( \pm 0.19 \mathrm{~dB})$ and at six months of age was $1.41 \mathrm{~dB}( \pm 0.29 \mathrm{~dB})$.

Table 2 shows the amount of suppression for the frequency bands, according to gender. No significant differences were noted in the amount of suppression between age $(p>0,5)$ and ears $(p>0,4)$. The amount of suppression was greater in male than in females for all frequency bands. For the $2.4 \mathrm{kHz}$ bandwidth the amount of suppression was significantly greater in male $(\mathrm{p}<0.01) 4.71 \mathrm{~dB}( \pm 0.44 \mathrm{~dB})$ than in females $3.15 \mathrm{~dB}( \pm 0.41 \mathrm{~dB})$ (Graphic 2 ). For the $3.2 \mathrm{kHz}$ frequency band no significant differences were noted in the amount of suppression between gender, 3.41 $\mathrm{dB}( \pm 0.44 \mathrm{~dB})$ for males and $3.20 \mathrm{~dB}( \pm 0.41$ dB) for females. For the $4.0 \mathrm{kHz}$ bandwidth the amount of suppression was significantly greater in males $(\mathrm{p}<0.01) 4.32 \mathrm{~dB}( \pm 0.39 \mathrm{~dB})$ versus $3.04 \mathrm{~dB}( \pm 0.38 \mathrm{~dB})$ observed for female infants (Graphic 3).

\section{Discussion}

In the present study, TEOAE level characteristics, with and without CAS, were investigated at the neonatal period and at six months of age in the same subjects, who were bilaterally tested.

The stimulus choice is a crucial challenge for OAE procedures. The appropriate stimulus can provide better results in a specific measurement. The linear mode stimulation has proven to be more sensitive for detected shifts in the TEOAE level at suppression experiments (Collet et al., 1990; Morlet et al., 1999; Ferguson et al., 2001; Guinan et al., 2003). However, despite the fact the linear stimulus is more sensitive to OAEs level, this mode has the expense of having collection of both middle ear and cochlea response components. Due to this recent studies were conducted with "non-linear" stimulation in order to analyse TEOAE suppression in a clinical set-up.
GRAPHIC 1. The mean levels of TEOAE with and without CAS for both ears of neonates at birth and six-month-old infants.

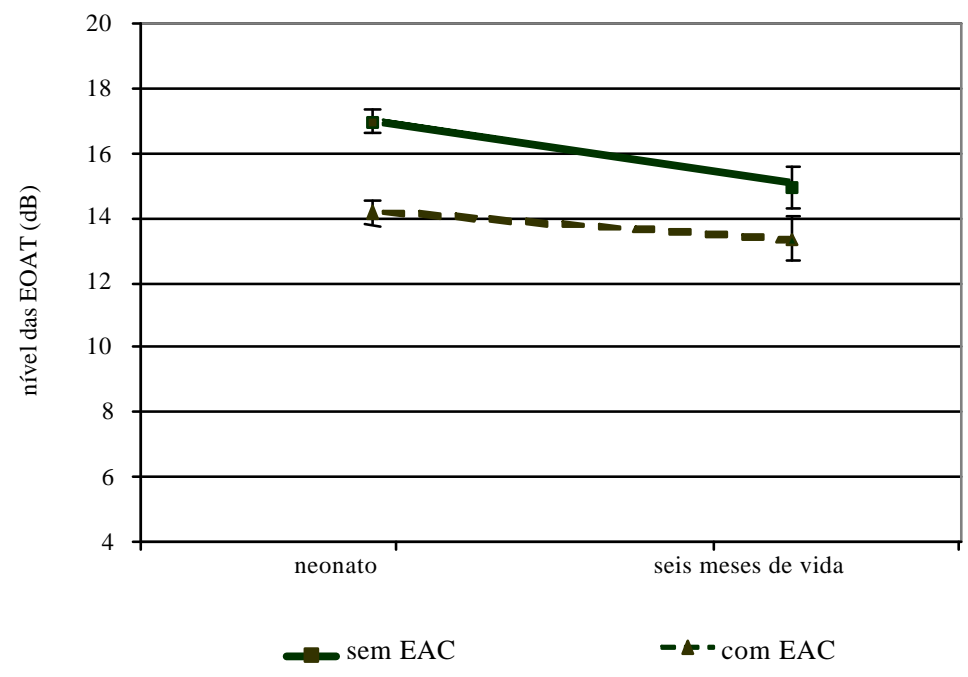

TABLE 2. TEOAE amount of suppression (dB) for frequency band, according to gender.

\begin{tabular}{c|c|c}
\hline \multirow{2}{*}{$\begin{array}{c}\text { Banda de Freqüência } \\
(\mathrm{kHz})\end{array}$} & Masculino & Feminino \\
\cline { 2 - 3 } & 4,71 & 3,15 \\
3,4 & 3,41 & 3,20 \\
4 & 4,32 & 3,04 \\
\hline
\end{tabular}

GRAPHIC 2. The $2.4 \mathrm{kHz}$ levels of TEOAE with and without CAS for both ages, according to gender.

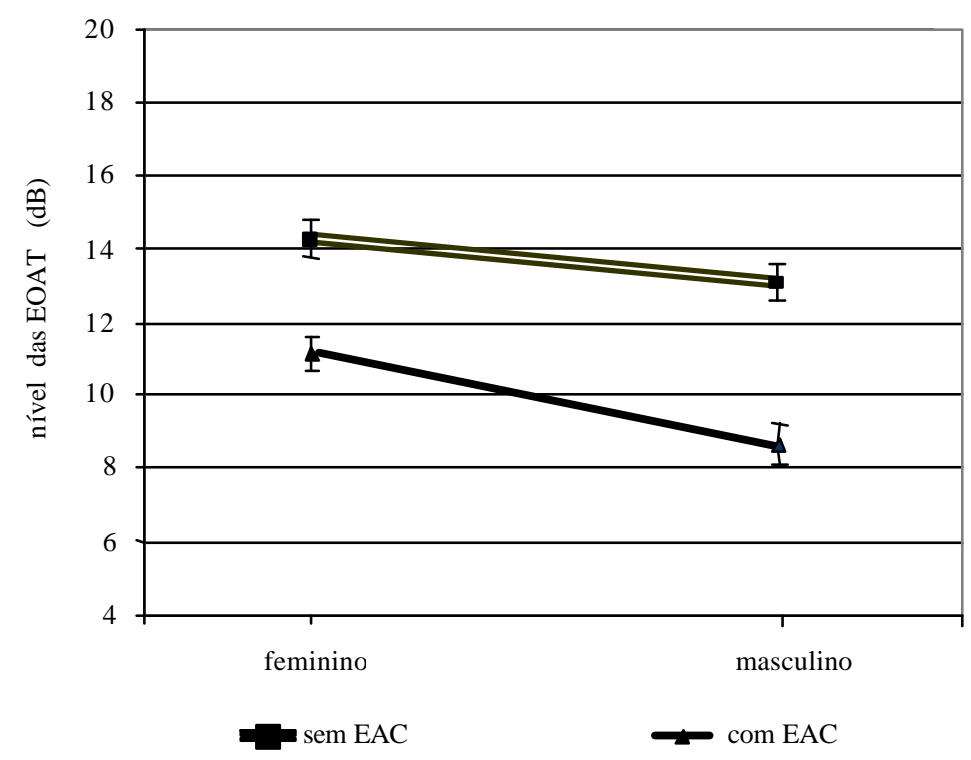


GRAPHIC 3. The $4.0 \mathrm{kHz}$ levels of TEOAE with and without CAS for both ages, according to gender ambas as idades segundo gênero.

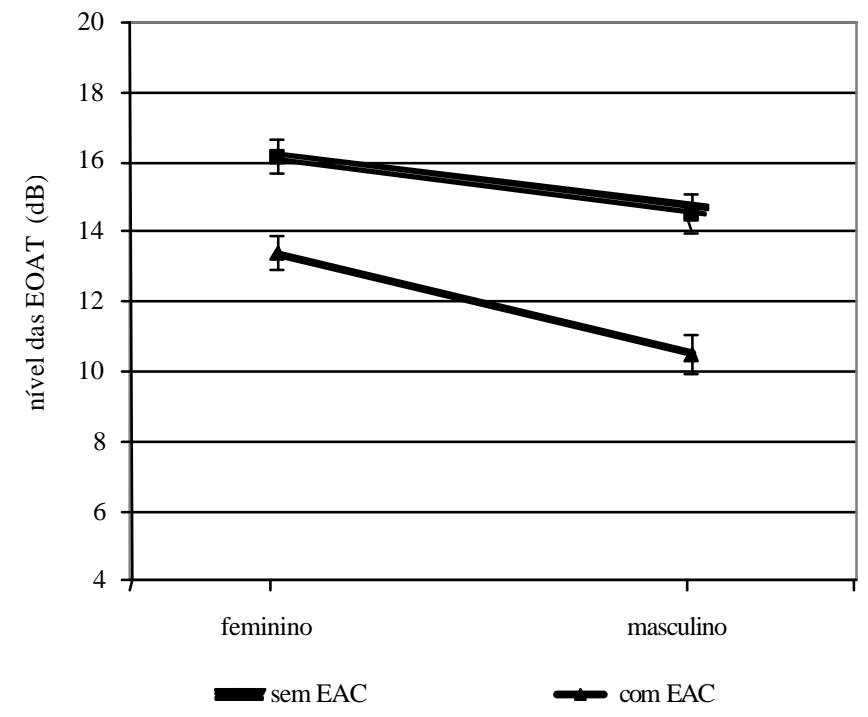

In this study TEOAE were recorded intentionally using the default non-linear stimulus, following other studies (De Ceulaer et al., 2001; Morlet et al.,2004). The Quickscreen mode of recording was selected because it ensured a near total elimination of meatal and probe-related acoustic artefacts, which was designed to achieve optimum results in neonate screening (Newmark et al., 1997; Garcia et al., 2002; Kemp, 2002; Carvallo, 2003; Durante et al., 2004a; Durante et al., 2004b).

The chosen parameters allowed shorter time procedures, desired when testing neonates. (Veuillet et al., 1991; Ryan and Piron,1994; Morlet et al.,1999; Durante and Carvallo, 2001; Durante and Carvallo, 2002).

The principal findings of the study were that TEOAE levels were smaller in the six-month-old group compared to the neonatal group and that the amount of TEOAE contralateral suppression decreased with age. Considering the total cochlear response, the amount of suppression was greater at neonatal period. The differences found at the infants could be explained by the postnatal growth of the middle ear (Eby; Nadol, 1986), and by the cochlear active mechanisms development (Morlet et al, 1996). The development of cochlear active mechanisms continued after onset of cochlear function, as reflected by OAE. OAE changes with age presumably occur as a consequence of cochlear active mechanisms development, although contribution of middle ear cannot be totally excluded. The importance of the TEOAE suppression effect is the association with mechanisms of central MOCS feedback in the peripheral auditory system, and it seems that the functional adult pattern of the TEOAE suppression appears gradually in infants.

The effects of age on contralateral suppression of OAEs are also reported by others studies in animals and humans (Kim et al., 2002; Jacobson et al., 2003) and show that functional decline of the MOCS with age precedes outer hair cells (OHC) degeneration. The importance of evaluation of the suppression effect of TEOAE be included in the test battery approach used in the hearing processing has been evidenced by recent researches which showed a reduced suppression effect in subjects with auditory processing disorder (Lonsbury-Martin et al., 2001; Sanches, 2003; Durante, 2004; Muchnik et al., 2004). Besides the OAE non suppression effect in subjects with auditory neuropathy empowered the use of OAE in the diagnosis of this pathology (Abdala et al., 2000; Hood; Berlin, 2000; Berlin et al., 2003; Hood et al., 2003).

\section{Gender differences}

Considering frequency-specific suppression effects, the age and ear influence were not significant. On the other hand gendereffects was significant, with a greater amount of suppression in males infants. Gender differences found in this study thus might represent differences in $\mathrm{OHC}$ population with a higher OHC count in females (Wright et al., 1987), a higher prevalence of spontaneous OAEs in female (Cassidy and Ditty, 2001), cochlear length significantly greater in males (Sato et al., 1991). The shorter cochlea in female could account for the TEOAE higher level. These findings could reflect differences in efferent cochlear inhibitory function between genders (Morlet et al., 1996; Newmark et al., 1997). These developmental changes appear to follow a systematic longitudinal course and represent a progression from the base (high-frequency place) to the apex (low-frequency place) of the cochlea (Morlet et al, 1996). 


\section{Conclusion}

The present investigation demonstrates that the TEOAE suppression decreased as a function of age. The association between contralateral acoustic stimulation and commercially available rapid TEOAE measurement system enables an easy and non-invasive study of the auditory efferent mechanism and seems to be clinically feasible to evaluate cochlear status and auditory efferent function in infants.

Acknowledgements: our thanks to FAPESP for supporting this work (Grant 98/10726-7). CEA - IME USP for the statistical analyses.

\section{References}

ABDALA, C.; M. A. E.; SININGER, Y. S.; STARR, A. Distortion product otoacoustic emission suppression in subjects with auditory neuropathy. Ear Hear., v. 21, n. 6, p. $542-553,2000$.

AZEVEDO, M. F Emissões Otoacústicas. In: FIGUEIREDO, M. S. Conhecimentos essenciais para entender bem Emissões Otoacústicas e BERA. São José dos Campos: Pulso, 2003. cap. 2, p. 35-83.

BERLIN, C. I.; MORLET, T.; HOOD, L. J. Auditory neuropathy/dyssynchrony: its diagnosis and management. Pediatr. Clin. North. Am., v. 50, n. 2, p. 331-340, 2003.

CARVALLO, R. M. M. Emissões Otoacústicas: Conceitos Básicos e Aplicações. In: CARVALLO, R. M. M. Fonoaudiologia informação para a formação: Procedimentos em Audiologia. Rio de Janeiro: Granabara, 2003. cap. 1, p. 22-41.

CASSIDY, J. W.; DITTY, K. M. Gender differences among newborns on a transient evoked otoacoustic emissions test for hearing. J. Music Therapy, v. 38, n. 1, p. 28-35, 2001.
CBPAI - Comitê Brasileiro sobre Perdas Auditivas na Infância: período neonatal. J. Cons. Fed. Fonoaudiol., n. 5, p. 3-7, 2000 .

COLLET, L.; KEMP, D. T.; VEUILLET, E.; DUCLAUX, R.; MOULIN, A.; MORGON, A. Effect of contralateral auditory stimuli on active cochlear micro-mechanical properties in human subjects. Hear. Res., v. 43, n. 2 e 3, p. 251-262, 1990.

DE CEULAER, G; YPERMAN, M.; DAEMERS, K.; VAN DRIESSCHE, K.; SOMERS, T.; OFFECIERS, F; GAVAERTS, P. Contralateral suppression of transient evoked otoacoustic emissions: normative data for a clinical test set-up. Otol. Neurotol., v. 22, n. 3, p. 350$355,2001$.

DURANTE, A. S. Supressão das emissões otoacústicas por transientes em neonatos com risco para alteração auditiva. 2004. 142 f. Tese (Doutorado em Ciências) Faculdade de Medicina, Universidade de São Paulo, São Paulo. 
DURANTE, A. S.; CARVAllo, R. M. M. Emissão Otoacústica Transitória Não-linear com estímulo Contralateral em lactentes. Pró-Fono R. Atual. Cient.,v. 13, n. 2, p. 271-276, 2001 .

DURANTE, A. S. D.; CARVALLO, R. M. M. Contralateral suppression of otoacoustic emissions in neonates. Int. J. Audiol., v. 41, n. 4, p. 211-215, 2002.

DURANTE, A. S.; CARVALlO, R. M. M.; COSTA, M. T. Z.; CIANCIARULlO, M. A.; VOEGELS, R. L.; TAKAHASHI, G M.; SOARES,A. V. N.; SPIR, E. G Programa de Triagem Auditiva Neonatal: Modelo de Implementação. Arq. Otorrinolaringol., v. 8, n. 1, p. 56-62, 2004a.

DURANTE, A. S.; CARVALLO, R. M. M.; COSTA, M. T. Z.; CIANCIARULlO, M. A.; VOEGELS, R. L.; TAKAHASHI, G M.; SOARES, A. V. N.; SPIR, E. G A implementação de programa de triagem auditiva neonatal universal em um hospital universitário brasileiro. Pediatr., São Paulo, v. 26, n. 2, p. 78-84, 2004 b.

EBY, T. L.; NADOL, J. B. Postnatal growth of the human temporal bone: implications for cochlear implants in children. Ann. Otol. Rhinol. Laryngol., v. 95, n. 4, p. $356-364,1986$, pt. 1 .

FERGUSON, M. A.; O'DONOGHUE, G M.; OWEN, V. Contralateral suppression of transient evoked otoacoustic emissions in patients with cerebello-pontine angle tumor. Ear Hear., v. 22, n. 3, p. 173-181, 2001.

GARCIA, C. F. D; ISAAC, M. L.; OLIVEIRA, J. A. A. Emissões otoacústicas evocadas transitórias: instrumento para a detecção precoce de alterções auditivas em recémnascidos a termo e pré-termo. R. Bras. Otorrinolaringol., v. 68, n. 3, p. 344-352, 2002.

GUINAN, J. J. JR.; BACKUS, B. C.; LILAONITKUL, W.; AHARONSON, V. Medial olivocochlear efferent reflex in humans: otoacoustic emission (OAE) measurement issues and the advantages of stimulus frequency OAEs. $J$. Assoc. Res. Otolaryngol., v. 4, n. 4, p. 521-540, 2003.

HILL, J. C.; PRACHER, D. K.; LUXON, L. M. Evidence for efferent effects on auditory afferent activity, and their functional relevance. Clin. Otolaryngol., v. 22, n. 5, p. 394-402, 1997.

HOOD, L. H.; BERLIN, C. I. Clinical applications of efferent suppression of otoacoustic emissions. In: AMERICAN ACADEMY OF AUDIOLOGY ANNUAL CONVENTION, 12., 2000, Chicago. Preliminary program \& registration book. Chicago, 2000. v. 1, p. 88 .

HOOD, L. J.; BERLIN, C. I.; BORDELON, J.; ROSE, K. Patients with auditory neuropathy/dys-synchrony lack efferent suppression of transient evoked otoacoustic emissions. J. Am. Ac. Audiol., v. 14, n. 6, p. 302-313, 2003.

JACOBSON, M.; KIM, S.; ROMNEY, J.; ZHU, X.; FRISINA, R. D. Contralateral suppression of distortion product otoacoustic emissions declines with age: a comparison of findings in CBA mice with humans listeners. Laringoscope, v. 113, n. 10, p. 707-713, 2003.
JCIH- Joint Committee on Infant Hearing. Joint Committee on Infant Hearing, 2000. Position Statement. Disponível em: <http://www.audiology.org/professional/ positions/jcih-early.php>. Acesso em: dez. 2005.

KEMP, D. T. Otoacustic emissions, their origin in cochlear function, and use. Br. Med. Bull., v. 63, p. 223$241,2002$.

KIM, S.; FRISINA, D. R.; FRISINA, R. D. Effects of age on contralateral suppression of distortion product otoacoustic emissions in humans listeners with normal hearing. Audiol. Neorootol., v. 7, n. 6, p. 348-357, 2002.

LAVIGNE-REBILLARD, M.; PUJOL, R. Hair cell innervation in the fetal human cochlea. Acta Otolaryngol., v. 105, n. 5 e 6, p. 398-402, 1988.

LIBERMAN, C. M.; KUJAWA, S. G The olivocochlear system and protection from acoustic injury: acute and chronic effects. In: BERLIN, C. I. The efferent auditory system: basic science and clinical application. San Diego: Singular Publishing Group Inc., 1999. p. 2-27.

LONSBURY-MARTIN, B. L.; MARTIN, G. K.; TELISCHI, F. Emissões Otoacústicas na prática clínica. In: MUSIEK, F. E.; RINTELMANN, W. F. Perspectivas atuais em avaliação auditiva. Barueri: Manole, 2001. cap. 6, p. 163-192.

MORLET, T.; GOFORTH, L.; HOOD, L. J.; FERBER, C.; DUCLAUX, R.; BERLIN, C. I. Development of human cochlear active mechanisms asymmetry: involvment of the medial olivocochlear system? Hear. Res., v. 134, n. 1 e 2, p. 153-162, 1999.

MORLET, T.; HAMBURGER, A.; KUINT, J.; ARI-EVEN, R. D.; GARTNER, M.; MUCHNIK, C.; COLLET, L.; HILDESHEIMER, M. Assessment of medial olivocochlear system function in pre-term and full-term newborns using a rapid test of transient otoacoustic emissions. Clin. Otolaryngol., v. 29, n. 2, p. 183-190, 2004.

MORLET, T.; PERRIN, E.; DURRANT, J. D.; LAPILLONE, A.; FERBER, C.; DUCLAUX, R.; PUTET, G.; COLLET, L. Development of cochlear active mechanisms in humans differs between gender. Neurosc. Lett. , v. 220, n. 1, p. 49-52, 1996.

MUCHNIK, C.; ROTH, D. A.; OTHMAN-JEBARA, R.; PUTTER-KATZ, H.; SHABTAI, E. L.; HILDESSHEIMER, M Reduced medial olivocochlear bundle system function in children with auditory processing disorders. Audiol. Neorootol., v. 9, n. 2, p. 107-114, 2004

MULDERS, W. H. A. M.; ROBERTSON, D. Inputs from the cochlea and the inferior colliculus converge on olivocochlear neurones. Hear. Res., v. 167, n. 1 e 2, p. 206-213, 2002.

NEWMARK, M.; MERLOB, P.; BRESLOFF, I.; OLSHA, M.; ATTIAS, J. Click evoked otoacoustic emissions interaural and gender differences in neonates. J. Basic. Clin. Physiol. Pharmacol., v. 8, n. 3, p. 133-139, 1997. 
RYAN, S.; PIRON, J. P. Functional maturation of the medial olivocochlear system in human neonates. Acta Otolaryngol., v. 114, n. 5, p. 485-489, 1994.

SANCHES, S. G G Efeito de supressão das emissões otoacústicas transientes em crianças com distúrbio do processamento auditivo. 2003. 126 f. Dissertação (Mestrado em Ciências) - Faculdade de Medicina, Universidade de São Paulo, São Paulo.

SATO, H.; SANDO, I.; TAKAHASHI, H. Sexual dimorphism and development of the human cochlea. Acta Otolaryngol., Stockholm, v. 111, n. 6, p. 1037-1040, 1991.
VEUILLET, E.; COLLET, L.; DUCLAUX, R. Effect of contralateral acoustic stimulation on active cochlear micromechanical properties in humans subjects: dependence on stimulus variables. J. Neurophysiol., v. 65, n. 3, p. 724-735, 1991 .

WARR, W. B.; GUINAN, J. J. Efferent innervation of the organ of Corti, two separate systems. Brain Res., v. 173, n. 1 , p. $152-155,1979$.

WRIGHT, A.; DAVIS, A.; BREDBERG, G.; ULEHLOVA, L.; SPENCER, H. Hair cell distributions in the normal human cochlea: a report of a European working group. Acta Otolaryngol., Stockholm, v. 436, p. 15-24, 1987. 